\title{
PRELIMINARY EVIDENCE OF LANDSCAPE-LEVEL STRUCTURE IN A POPULATION OF A PERENNIAL HERB, Cypella herbertii (IRIDACEAE)
}

\section{EVIDENCIA PRELIMINAR DE LA EXISTENCIA DE ESTRUCTURACIÓN EN EL NIVEL DE PAISAJE EN UNA POBLACIÓN DE UNA HIERBA PERENNE, Cypella herbertii (IRIDACEAE) Mariano Devoto ${ }^{1}$ y Diego Medan ${ }^{1}$}

\begin{abstract}
We present preliminary evidence for the existence of a genetic landscape-level structuring that might be a consequence of depressed pollen flow across heavily grazed populations of Cypella herbertii.
\end{abstract}

Key words: Cypella herbertii, Iridaceae, grazing, disturbance, genetic structure.

\section{Resumen}

Presentamos evidencia preliminar de la existencia de una estructura genética en el nivel de paisaje en una población de Cypella herbertii. Esto podría ser consecuencia de la reducción en el flujo de polen que ocurre en las poblaciones intensamente pastoreadas de esta especie.

Palabras clave: Cypella herbertii, Iridaceae, pastoreo, disturbio, estructuración genética.

\section{Introduction}

The effects that ecological disturbances can have on key aspects of plant reproduction such as pollination, selfing rates, inbreeding depression and the evolution of mating systems have been the focus of much research (e.g. Cruden, 1977; Feinsinger et al., 1987; Arroyo \& Squeo, 1990; Lloyd, 1992; Totland 1993; Potts et al., 2001). This issue which is starting to be addressed world-wide is of major importance to ecosystems function and conservation (Brazilian Ministry of the Environment, 1999). However, there is still a lack of concrete data regarding the impact of cattle grazing on pollinator communities and its detrimental effect on plant reproduction.

In the Flooding Pampa grasslands (Buenos Aires Province, Argentina) Roitman (1995) found that the disturbance produced by grazing strongly reduced the quantity and quality of pollinators available for a population of Cypella herbertii (Herb.) Herbert (Iridaceae). Comparing cattle-free enclosures against the heavily grazed surroundings, Roitman (1995) reported (a) a highly significant 2.4 fold increase in the abundance of available pollinators inside the enclosures, and (b) the presence of a specialist pollinator to $C$. herbertii (an oil-collecting apid bee from the genus Chalepogenus) exclusively inside the enclosures.

In entomophilous species, shortage of pollinators can isolate at the landscape level portions of a population that would otherwise be linked through pollen flow. One such population would gradually become genetically and spatially structured (Hauser \& Loeschcke, 1994) due to an increase in genetic similarity between close neighbors together with growing dissimilarity between groups of plants farther apart. The consequence of a phenomenon of this nature would be inbreeding depression in matings between close neighbours (Figure 1a) together with outbreeding depression with increasing distance from the pollen source (Figure 1b). If both inbreeding and outbreeding depression occur within a population, there should be an intermediate degree of outbreeding at which its overall deleterious effect is minimized leading to an optimal outcrossing distance (Figure 1c; Waser \& Price, 1983, 1989). These phenomena have been reported occurring on spatial scales that range from meters to tens of kilometers (Waser \& Price, 1983; Willson, 1984; Sobrevila, 1988).

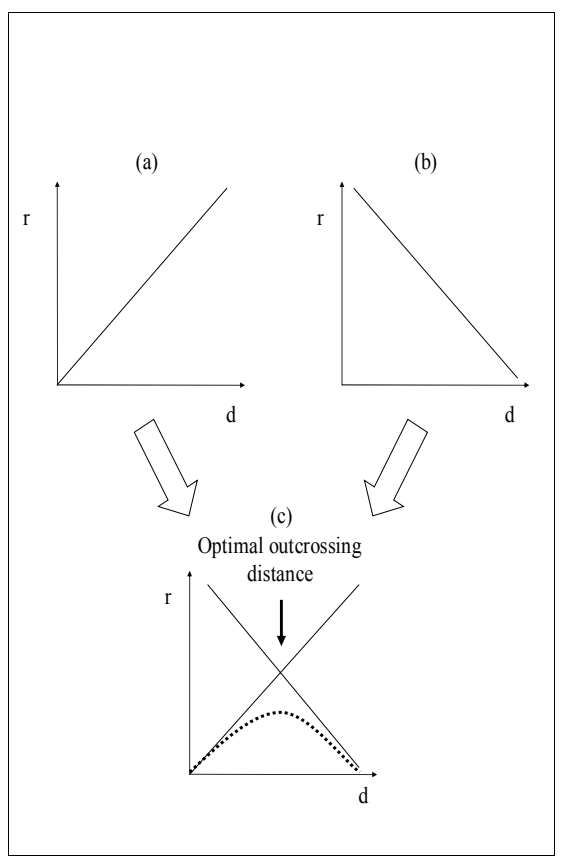

Figure 1. Effect of crossing distance on maternal reproductive success in the occurrence of (a) inbreeding depression, (b) outbreeding depression, and (c) inbreeding and outbreeding depression simultaneously, leading to an optimal outcrossing distance (Waser \& Price, 1983, 1989). r, maternal 
reproductive success; $d$, distance to the source of pollen.

In this paper, we test the hypothesis that in a population of Cypella herbertii under a long-dating grazing history, the reduction in pollen flow associated to the reported decrease in pollinators causes a landscape-level structuring (following the process described above and in Figure 1).

\section{Methods}

Study site and focal species

The Salado River basin ( $\left(\begin{array}{llll}6^{\circ} 30^{\prime} \mathrm{S}, 58^{\circ} 30^{\prime} \mathrm{W}\end{array}\right)$ constitutes the main portion of the Flooding Pampa, which extend over $58000 \mathrm{~km}^{2}$ in Buenos Aires Province, Argentina. In this region, temperate weather with a mean annual rainfall of $900 \mathrm{~mm}$ together with halomorphic, poorly drained soils and summer droughts determine natural grasslands to be the dominant vegetation type (León, 1975; Cabrera, 1976; León et al., 1979). However, for the past century, these grasslands have been uninterruptedly cattlegrazed and the actual flora includes many adventitious species associated with grazing conditions (Sala et al., 1986). In a floodplain rangeland located at the "Las Chilcas" ranch two permanent enclosures precluding cattle grazing were established 4 (Exc 4) and 19 (Exc 19) years prior to the beginning of the essay. These two enclosures are ca. 2 ha each and are ca. $4 \mathrm{~km}$. apart. From each a sample of 15 plants of $C$. herbertii was collected. The area surrounding both enclosures was year-long grazed by a cattle stocking rate of 0.5 animal/ha. No plants or pollen from outside the enclosures (grazed area) were used in the experiments described below (however, see Medan \& Devoto (2002) for an essay where they were used). Native tall grasses dominated the community inside the enclosures while the grazed site was dominated by forbs, mainly exotic (Chaneton et al., 1988). In May 1997 all plants were collected, transplanted to plastic boxes $(80 \times 40 \times 25 \mathrm{~cm})$ and placed in a glasshouse at the "Lucien Hauman" Botanical Garden (Faculty of Agronomy, University of Buenos Aires) (34 $35^{\prime} 27^{\prime \prime}$ S $\left.58^{\circ} 28^{\prime} 49^{\prime \prime} \mathrm{W}\right)$ where the essay described here was carried out.

Focal species. $C$. herbertii is one of several Iridaceae known to produce lipidic oils by special floral glands, called elaiophores, as a floral reward to their highly specific bee pollinators (Buchmann, 1987; Vogel, 1988). C. herbertii is a perennial bulbiferous herb that ranges from south Brasil to north- eastern Argentina. Its actinomorphic flowers have six orange-yellow tepals; the outer three being much bigger $(3-4.5 \mathrm{~cm}$ long) than the inner ones (0.9-1.4 cm long). $C$. herbertii produces multiseeded capsules. Previous work on the species revealed $C$. herbertii has a remarkably low automatic fruit formation although it is almost completely self-compatible (Devoto \& Medan, 2002).

An experiment was conducted in 1999 in order to test in a preliminary way the existence of genetic structuring in terms of an optimal outcrossing distance and the resulting optimal outcrossing distance in a population of $C$. herbertii. If such a structuring was present, reproductive output (i.e. fruit and/or seed set) would gradually increase to a certain mating distance reaching a maximum value beyond which it would decrease (Waser \& Price, 1983, 1989). In the experiment five plants from each enclosure worked as pollen receptors, on whose flowers matings were performed (i.e. they were maternal plants) and all worked as possible pollen donors. In each plant, pollination of each flower was performed with pollen from one of three sources as follows: (i) the same flower, (ii) another individual in the same enclosure less than $100 \mathrm{~m}$ away (Short Distance Crossing SDC), (iii) an individual in the other enclosure (Long Distance Crossing - LDC). For matings (ii) and (iii), where external (i.e. not from the same flower) pollen was needed, pollen-donor flowers were randomly chosen among open flowers from the corresponding source groups. Flowers used as pollen donors were only used once and then removed from the plants. Only one kind of pollen was placed on each individual flower. All flowers from the maternal plants were pollinated during the 1999 flowering season, totaling $\mathrm{n}=42$ pollinations, all treatments considered (see Table 1 for details on total number of flowers used in each treatment). Following matings, fruit set and seed number per fruit were calculated.

The square-root transformation for seed set and the arcsine square-root transformation for percentage of fruit set were used for analysis (Sokal \& Rohlf, 1994). All data were analyzed using ANOVA tools of Statistica (StatSoft, Inc., 1999). For all analysis, when the $\mathrm{F}$ test for treatments was significant $(\mathrm{P}<0.05)$, Tukey's honest significant difference (HSD) multiple pair-wise comparisons between means were performed. Deviations are standard errors (SE) unless otherwise noted.

\section{Results and discussion}

Crossing distance had no effect on fruit set (data not shown). However, it had a highly significant effect $(\mathrm{F}=8.54, \mathrm{P}<0.0001)$ on seed set. Seed set significantly differed among crossing distances (Table 1). SDC yielded $192.6 \%$ and $53.1 \%$ more seeds per capsule than self-pollinations and LDC, respectively. Likewise, LDC produced $91.1 \%$ more seeds per capsule than self-pollinations. Independent tests within each enclosure were still significant for the difference between self-pollination and SDC, but LDC was not significantly different from either one (Table $1)$. 
On the maternal plants of the enclosures, seed set from outcrossings is maximal if the pollen comes from individuals within the same enclosure, and it is

Table 1. Effect of crossing distance on seed set in two populations of $C$. herbertii. Means followed by the same letter in a column are not significantly different $(\mathrm{P}>0.05$, Tukey's HSD)

\begin{tabular}{|l|l|l|l|}
\hline $\begin{array}{l}\text { Pollen source (distance } \\
\text { to maternal plant) }\end{array}$ & Exc 19 (n flowers) & Exc 4 (n flowers) & $\begin{array}{l}\text { Both } \\
\text { pooled }\end{array}$ \\
\hline Self-pollination & $39.5 \pm 4.3(5) \mathrm{a}$ & $48.3 \pm 9.6(7) \mathrm{a}$ & $45.1 \pm 6.2(12) \mathrm{a}$ \\
\hline $\begin{array}{l}\text { Short-distance crossing } \\
(<100 \mathrm{~m})\end{array}$ & $144.9 \pm 31.4(6) \mathrm{b}$ & $120.8 \pm 18.8(8) \mathrm{b}$ & $132.0 \pm 17.4(14) \mathrm{b}$ \\
\hline $\begin{array}{l}\text { Long-distance crossing } \\
(\sim 4 \mathrm{~km})\end{array}$ & $98.5 \pm 22.1(7) \mathrm{ab}$ & $78.0 \pm 11.9(9) \mathrm{ab}$ & $86.2 \pm 11.2(16) \mathrm{c}$ \\
\hline
\end{tabular}

evolutionary trends in plants. Academic Press, New York, pp. 205- 227.

Bazzaz F.A. 1979. Physiological ecology of plant succession. Annu. Rev. Ecol. Syst. 10: 351-371.

Brazilian Ministry of the Environment. 1999. International Pollinators Initiative: The São Paulo declaration on pollinators. Brasilia.

Buchmann S.L. 1987. The ecology of oil flowers and their bees. Annu. Rev. Ecol. Syst. 18: 343-369.

Cabrera A.L. 1976. Regiones minimal for self-pollinations and long distance crossings.

The results shown here, though still un-replicated, suggests the existence of an optimal outcrossing distance which could be a consequence of depressed pollen flow across this population of $C$. herbertii.

In $C$. herbertii, inbreeding depression effects are evident in seed set, but not in fruit set stage. Similar results, where inbreeding depression is manifested only in some stages throughout life-cycle, were reported for other species (e.g. Schaal, 1984; Waller, 1984; Charlesworth \& Charlesworth, 1987; Karron, 1989; Kephart et al., 1999).

In summary, this study provides preliminary evidence that suggests that a process of genetic structuring could be taking place in this population of Cypella herbertii as a consequence of depressed pollen flow across the landscape. This sub-structuring is manifested, in part as a negative effect of inbreeding and outbreeding on a fitness component such as seed set. This evidence linked to the previously reported fact that the reproductive output of $C$. herbertii is extremely sensitive to lack of pollinators (unmanipulated flowers yield an average $3.7 \%$ fruit set, Devoto \& Medan, 2002) strongly draws the attention upon the likely negative consequences that a sustained grazing pressure could have on this species. Finally, the evidence presented here advocates for further observations on this and other species on comparable heavily grazed systems.

\section{Acknowledgements}

We thank the owners of the Las Chilcas ranch for permission to carry out material collection inside their property. G.G. Roitman helped us in the field. N. Bartoloni assisted us with statistical analysis. This work was done during an undergraduate scholarship granted by the University of Buenos Aires to M. Devoto.

\section{References}

Arroyo M.T.K. \& Squeo F. 1990. Relationship between plant breeding system and pollination. In: Kawano S. (ed.) Biological approaches and
Fitogeográficas Argentinas. In: Enciclopedia Argentina de Agricultura y Jardinería. $2^{\text {nd }}$ Edition, Acme, Buenos Aires.

Chaneton E.J.; Facelli J.M. \& León R.J.C. 1988. Floristic changes induced by flooding on grazed and ungrazed lowland grasslands in Argentina. J. Range Manage. 41: 495-499.

Charlesworth D. \& Charlesworth B. 1987. Imbreeding depression and its evolutionary consequences. Annu. Rev. Ecol. Syst. 18: 237-268.

Cruden R.W. 1977. Pollen-ovule ratios: a conservative indicator of breeding systems in flowering plants. Evolution. 31: 32-46.

Devoto M. \& Medan D. 2003, online 2002. Effects of grazing disturbance on the reproduction of a perennial herb, Cypella herbertii (Lindl.) Herb. (Iridaceae). Plant Systematics and Evolution. 243: 165-173.

Feinsinger P., Beach J.H., Linhart Y.B. \& Busby H.R. 1987. Disturbance, pollinator predictability, and pollination success among Costa Rican cloud forest plants. Ecology. 68: 1294-1305.

Hauser T.P. \& Loeschcke V. 1994. Inbreeding depression and mating-distance dependent offspring fitness in large and small populations of Lychnis flos-cuculi (Caryophyllaceae). J. Evol. Biol. 7: 609-622.

Karron J.D. 1989. Breeding systems and levels of inbreeding depression in geographically restricted and widespread species of Astragalus (Fabaceae). Am. J. Bot. 76: 331-340.

Kephart S.R., Brown E. \& Hall J. 1999. Inbreeding depression and partial selfing: evolutionary implications of mixed-mating in a coastal endemic, Silene douglassi var. oraria (Caryophyllaceae). Heredity. 82: 543-554.

León R.J.C. 1975. Las comunidades herbáceas de la región Castelli-Pila. In: Monogr. 5, Comisión de Investigaciones Científicas, La Plata. : 75-107.

León R.J.C., Burkart S.E. \& Movia C.P. 1979. Relevamiento fitosociológico del pastizal del norte de la Depresión del Salado. La Vegetación de la República Argentina. Ser. Fitogeogr. 17 Instituto Nacional de Tecnología Agropecuaria, Buenos Aires. 
León R.J.C., Rusch G.M. \& Oesterheld M. 1984. Pastizales pampeanos - impacto agropecuario. Phytocoenol. 12: 201-218.

Lloyd D.G. 1992. Self- and cross-fertilization in plants. II. The selection of self-fertilization. Int. J. P1. Sci. 153: 370-380.

Loreti J., Oesterheld M. \& León R.J.C. 1994. Efectos de la interacción del pastoreo y la inundación sobre Paspalum dilatatum, un pasto nativo de la Pampa Deprimida. Ecología Austral. 4: 49-58.

Potts S.G., Dafni A. \& Ne'eman G. 2001. Pollination of a core flowering shrub species in Mediterranean phrygana: variation in pollinator diversity, abundance and effectiveness in response to fire. Oikos. 92: 71-80.

Price M.V. \& Waser N.M. 1979. Pollen dispersal and optimal outcrossing in Delphinium nelsonii. Nature. 277: 294-296.

Roitman G.G. 1995. Comportamiento reproductivo de dos comunidades de la Depresión del Salado. Magister Scientiae Thesis. University of Buenos Aires.

Sala O.E., Oesterheld M., León R.J.C. \& Soriano A. 1986. Grazing effects upon plant community structure in subhumid grassland of Argentina. Vegetatio. 67: 27-32.

Schaal B.A. 1984. Life history variation, natural selection and maternal effects in plant populations. In: Dirzo R., Sarukhan J. (eds.) Perspectives on plant population ecology. Sinauer, Sunderland, MA. : 188-206.

Sobrevila C. 1988. Effects of distance between pollen donors and pollen recipient on fitness components in Espeletia schultzii. Amer. J. Bot. 75: 701-724.
Sokal R.R. \& Rohlf F.J. 1994. Biometry: the principles and practice of statistics in biological research. $3^{\text {rd }}$ edition. W. H. Freeman \& Co. New York.

Soriano A. 1991. Río de la Plata Grasslands. In: Coupland R.T. (ed.) Ecosystems of the world 8A. Natural Grasslands. Introduction and Western Hemisphere. Elsevier, Amsterdam.: 367-407.

StatSoft, Inc. 1999. STATISTICA for Windows [Computer program manual]. Tulsa, $\mathrm{OK}$.

Vogel S. 1988. Ölblumensymbiosen - Parallelismus und andere Aspekte ihrer Entwicklung in Raum und Zeit. Z. Zool. Syst. Evolut.-forsch. 26: 341362.

Waller D.W. 1984. Differences in fitness between seedlings derived from cleistogamous and chasmogamous flowers in Impatiens capensis. Evolution. 38: 427-440.

Waser N.M. \& Price M.V. 1983. Optimal and actual outcrossing in plants and the nature of plant pollinator interaction. In: Jones C. E., Little R.J. (eds.) Handbook of experimental pollination biology. Van Nostrand Reinhold, New York.: 341359.

Waser N.M \& Price M.V. 1989. Optimal outcrossing in Ipomopsis aggregata: seed set and offspring fitness. Evolution. 43: 1097-1109.

Willson M.F. 1984. Mating patterns in plants. In: Dirzo R., Sarukhan J. (eds.) Perspectives on plant population biology. Sinauer, Sunderland, MA. : 261-276.

\footnotetext{
${ }^{1}$ Cátedra de Botánica, Facultad de Agronomía de la Universidad de Buenos Aires. Av. San Martín 443 - (C1417 DSE) - Buenos Aires, Argentina. Correo eléctronico: mdevoto@agro.uba.ar
} 